\title{
Pengaruh Behavior Therapy Dengan Teknik Modelling Dalam Meningkatkan Speaking Skill Mahasiswa Bimbingan Konseling
}

\author{
Kartini Ayu Trisnawati ${ }^{1}$, Raup Padillah ${ }^{2}$. \\ ${ }^{1}$ Bimbingan Konseling, Universitas PGRI Banyuwangi \\ ${ }^{2}$ Teknologi Pembelajaran, Universitas PGRI Banyuwangi \\ Email: kartiniayu017@gmail.com/ raup.padillah@gmail.com
}

\begin{abstract}
Counseling guidance students are counselor candidates. One of the competencies possessed by a counselor is the ability in conversation and can enjoy the ongoing conversation. This ability is a speaking skill. From the observations of researchers while providing lecture material and practice counseling, there are still many students of counseling study programs at PGRI Banyuwangi University who have low ability to speak. In counseling science, efforts to change behavior with behavioral modeling techniques. This research is an experimental research approach. In this study, observations make twice, that is, observations made before and after treatment. Data collection methods used in this study are observation and documentation. The results of data analysis using a statistical test with a T-Test and looking for a comparison between pre-test and post-test. This research has conducted on students of Guidance and Counseling Study Program PGRI Banyuwangi University. Based on the data and instruments provided, 17 res ondents to have low Speaking Skill abilities. Based on the results of SPSS data, behavioral therapy counseling with modeling techniques used to improve students' speaking skills. The technique is a recommendation to overcome the lack of speaking skills in students. From the correlation analysis between pretest and post-test, resulting in a correlation number of 0.213 with a chance value below 0.05 which is equal to 0.000 .
\end{abstract}

Keywords : Behavior Therapy; Modelling Technique; Speaking Skill; Counseling.

\section{PENDAHULUAN}

Konselor adalah seseorang yang memiliki keahlian dalam bidang pelayanan konseling sebagai tenaga profesional (Hartono, et al. 2010). Salah satu kompetensi yang harus dimiliki seorang konselor adalah keahlian dalam berbincang dan dapat menikmati percakapan yang berlangsung (Gladding, ST. 2012). Kemampuan ini sangat menentukan cara konselor dalam mengkomunakisan solusi permasalahan klien.

Mahasiswa yang memiliki kemampuan berbicara yang rendah, berdampak pada keaktifan pada saat perkuliahan dan pada aktifitas diluar perkuliahan. Sebagai mahasiswa bimbingan konseling, hal ini menjadi penghambat mahasiswa dalam mendapatkan hasil yang maksimal disetiap mata kuliah yang harus ditempuh.

Speaking skill (kemampuan berbicara) merupakan kemampuan mengucapkan bunyibunyi artikulasi atau kata-kata untuk mengekspresikan, menyatakan, serta menyampaikan pikiran, gagasan dan perasaan (Suhartono, 2005). Tujuan dari berbicara adalah untuk memberitahukan, melaporkan, menghibur, membujuk, dan meyakinkan seseorang yang terdiri dari aspek kebahasaan dan nonkebahasaan (Nurbiana, 2005). Selain penguasaan materi dan teknik konseling yang tepat, kemampuan berbicara pada seorang konselor menjadi tolak ukur profesionalitas dan totalitas seorang konselor dalam menekuni profesinya.

Dari hasil observasi peneliti selama memberikan materi perkuliahan dan praktikum 
konseling, masih banyak mahasiswa program studi bimbingan konseling Universitas PGRI Banyuwangi yang kemamampuan berbicaranya rendah. Justifikasi ini berdasarkan hasil pengamatan peneliti terhadap mahasiswa yang kurang begitu baik dalam berkomunikasi.

Aspek kemampuan berbahasa merupakan salah satu aspek yang menjadi perhatian khusus peniliti slama ini dikarenakan pentingnya kemampuan tersebut dalam proses konseling. Indikator yang diamati terkait kemampuan berbahasa mahasiswa antara lain; tata bahasa, kosa kata, kefasihan, kemudahan , dan ketepatan bicara, isi pembicaraan, pemahaman menyangkut tingkat keberhasilan komunikasi dan kekomunikatifan, lafal dan ucapan (Shihabuddin, 2009). Mahasiswa membutuhkan role model dalam proses menguasai kemampuan berbahasa dengan baik. Dalam keilmuan konseling, upaya dalam merubah tingkah laku dapat dilakukan dengan teknik modelling.

Teknik modelling merupakan salah satu teknik dalam konseling behavioral yang bertujuan untuk mengubah perilaku konseli dengan mengamati dan mencontoh tingkah aku model-model yang ada (Corey, G. 2015). Hal ini yang menajdi dasar peneliti untuk melakukan penelitian dalam meningkatkan speaking skill mahasiswa bimbingan konseling. Penelitian ini perlu dilakukan dalam upaya membantu mahasiswa terkait masalah kemampuan berbicara yang peranannya sangat vital dalam dunia konseling (Sanyata, S. 2012).

\section{METODE PENELITIAN}

\section{Tahapan Penelitian}

Pada penelitian ini terdapat dua variabel yaitu variabel bebas (Independent Variable) adalah penggunaan "Behavior Therapy dengan Teknik Modelling", dan variabel terikat (DependentVariable) adalah "Speaking Skill". Penelitian ini merupakan penelitian pendekatan eksperimen karena gejala yang diteliti ditentukan pada mahasiswa bimbingan konseling Universitas PGRI Banyuwangi. Secara konseptual rancangan penelitian dapat digambarkan sebagai berikut:

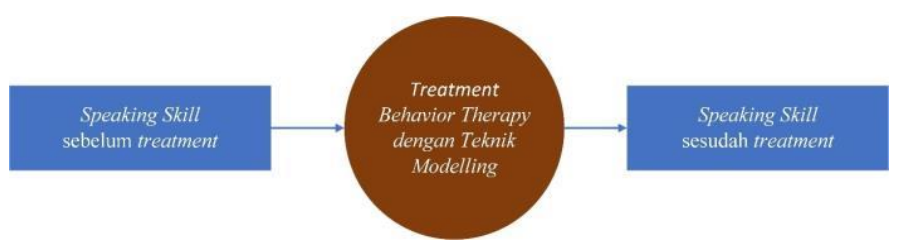

Gambar 1. Tahapan Penelitian

\section{Deskripsi Penelitian}

Pada penelitian ini, observasi dilakukan sebanyak 2 kali yaitu: 1). Observasi yang dilakukan sebelum treatment. 2). Observasi yang dilakukan sesudah treatment. Observasi yang dilakukan sebelum treatment $(\mathrm{Ol})$ disebut pre-test, dan observasi yang dilakukan sesudah treatment $(\mathrm{O} 2)$ disebut post-test. Perbedaan antara $\mathrm{Ol}$ dan $\mathrm{O} 2$ diasumsikan merupakan efek dari treatment atau eksperimen. Untuk lebih jelasnya dapat dilihat pada gambar berikut (Wahyudi, 2017). 


\section{$\mathrm{O}_{1} \quad \mathrm{X} \quad \mathrm{O}_{2}$}

Gambar 2. Alur Eksperimen

Keterangan :

$\mathrm{O} \quad$ : Sebelum treatment (pre-test)

X : Treatment (Behavior Therapy dengan Teknik Modelling)

O2 : Sesudah treatment (post test)

\section{Populasi dan Sampel}

Dalam penelitian ini populasi penelitiannya adalah seluruh mahasiswa program studi bimbingan konseling Universitas PGRI Banyuwangi. Pada penelitian ini, sampel diambil sejumlah 34 mahasiswa bimbingan konseling, diambil dari 17 mahasiswa setiap angkatan. 17 mahasiswa setiap angkatan dianggap sudah mewakili keseluruhan mahasiswa program studi bimbingan konseling Universitas PGRI Banyuwangi.

Instrumen dalam penelitian ini adalah alat yang digunkan untuk mendapatkan data tentang speaking skill mahasisaw sebelum dan sesudah dilakukan behavior therapy dengan teknik modelling. Peneliti menggunakan instrumen observasi untuk mengetahui speaking skill mahasiswa sebelum dan sesudah behavior therapy dengan teknik modelling dan menggunakan tabel rekapitulasi hasil observasi terhadap mahasiswa bimbingan konseling yang menjadi subyek pada penelitian ini.

Metode pengumpulan data yang digunakan pada penelitian ini adalah observasi dan dokumentasi (vidio \& foto) sebagai pelengkap. Observasi dilakukan dengan menggunakan instrumen yang sudah dibuat untuk mengukur speaking skill mahasiswa bimbingan konseling sebelum dan dilakukan behavior therapy dengan teknik modelling (Sugiyono, 2008).

Teknik analisa data menggunakan analisa statistik menggunakan t- tes dan mencari perbandingan antara pre-test dan post-test yang akan menjawab sejauh mana pengaruh behavior therapy dengan teknik modelling terhadap speaking skill mahasiswa program studi bimbingan konseling (Arikunto, S. 2002).

\section{HASIL DAN PEMBAHASAN}

Hasil Observasi berdasarkan data dan instrument yang diberikan, diperoleh 34 responden yang terindikasi kemampuan Speaking Skill rendah. Setelah dilakukan treatment, perubahan perilaku responden diamati untuk mengetahui perubahan variable speaking skill pada responden. Bentuk perubahan terebut merupakan hasil dari post test. Dari hasil penilaian diperoleh data speaking skill pada mahasiswa sebagai berikut: 
Tabel 1. Data Peretest, Posttest Kelompok Eksperimen

\begin{tabular}{|c|c|c|c|c|}
\hline NO & SAMPEL & PRETEST & POSTTEST & GAIN SCORE \\
\hline 1 & S1 & 94 & 145 & 51 \\
\hline 2 & S2 & 98 & 139 & 41 \\
\hline 3 & S3 & 101 & 140 & 39 \\
\hline 4 & S4 & 94 & 142 & 48 \\
\hline 5 & S5 & 100 & 135 & 35 \\
\hline 6 & S6 & 95 & 138 & 43 \\
\hline 7 & S7 & 93 & 137 & 44 \\
\hline 8 & S 8 & 103 & 139 & 36 \\
\hline 9 & S9 & 95 & 139 & 44 \\
\hline 10 & S10 & 94 & 137 & 43 \\
\hline 11 & S11 & 92 & 138 & 46 \\
\hline 12 & S12 & 99 & 142 & 43 \\
\hline 13 & S13 & 103 & 141 & 38 \\
\hline 14 & S14 & 98 & 143 & 45 \\
\hline 15 & S15 & 102 & 137 & 35 \\
\hline 16 & S16 & 100 & 141 & 41 \\
\hline 17 & S17 & 92 & 140 & 48 \\
\hline JUMLAH & $\mathbf{1 6 5 3}$ & $\mathbf{2 3 7 3}$ & $\mathbf{7 2 0}$ \\
\hline RATA-RATA & $\mathbf{9 7 , 2 4}$ & $\mathbf{1 3 9 , 5 9}$ & $\mathbf{8 0}$ \\
\hline
\end{tabular}

Data dalam tabel 1 menunjukan terjadi peningkatan skor dari hasil pretes ke posttest pada masing-masing sampel yang ditunjukan oleh Gain Skor-nya. Deskripsi dari masingmasing sampel divisualisasikan dalam grafikberikut:

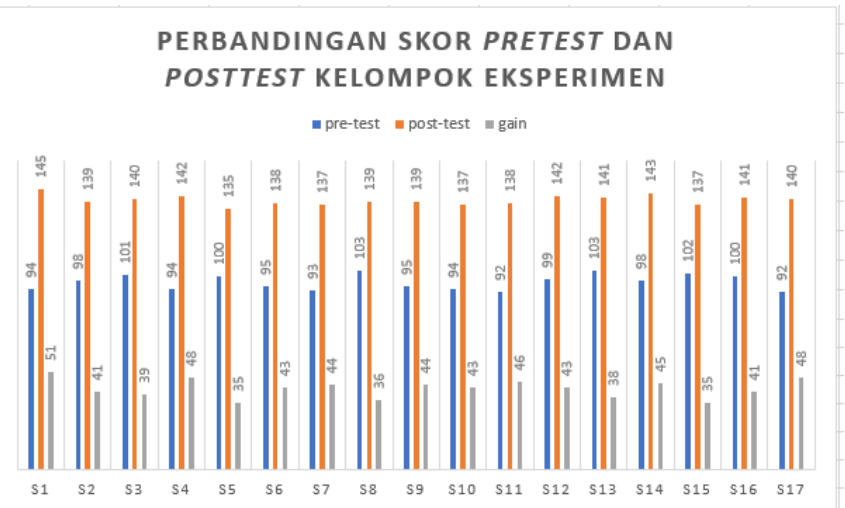

\section{Gambar 3. Grafik Perbandingan Skor Pretest dan Posttest Kelompok Eksperimen}

Dari grafik tersebut dapat diketahui bahwa terjadi peningkatan skor dari pretest ke posttest. Hal ini merupakan indikasi bahwa Konseling behavior therapy dengan teknik modelling mampu meningkatkan kemampuan speaking skill pada mahasiswa.

Untuk mengetahui efektifitas konseling behavior therapy dengan teknik modelling dalam meningkatkan kemampuan speaking skill, dilakukan uji statistik dengan correlated data paired sampel t-test dimaksudkan untuk mengetahui pengaruh dari variabel bebas terhadap variabel terikat dilihat dari perbedaan pretest dengan posttest. Berikut adalah tabel hasil analisis output dai SPSS: 
Tabel 2. Paired Samples Statistic Pretest-Posttest

Paired Samples Statistics

\begin{tabular}{|c|c|c|c|c|c|}
\hline & & Mean & $\mathrm{N}$ & Std. Deviation & Std. Error Mean \\
\hline Speaking & Pretest & 97.2353 & 17 & 3.84918 & .93356 \\
\hline Skill & Posttest & $1.3959 \mathrm{E} 2$ & 17 & 2.55095 & .61870 \\
\hline
\end{tabular}

Tabel 3. Paired Samples Test Pretest-Posttest

\begin{tabular}{|l|l|r|r|r|}
\hline \multicolumn{5}{|c|}{ Paired Samples Correlations } \\
\hline & & $\mathrm{N}$ & \multicolumn{1}{|c|}{ Correlation } & \multicolumn{1}{c|}{ Sig. } \\
\hline $\begin{array}{l}\text { Speaking } \\
\text { Skill }\end{array}$ & Pretest \& Posttest & & & \\
\hline
\end{tabular}

Tabel 4. Paired Samples Correlation Pretest Posttest

\begin{tabular}{|c|c|c|c|c|c|c|c|c|c|}
\hline \multicolumn{10}{|c|}{ Paired Samples Test } \\
\hline & & \multicolumn{5}{|c|}{ Paired Differences } & \multirow{3}{*}{$\mathrm{t}$} & \multirow{3}{*}{ df } & \multirow{3}{*}{$\begin{array}{l}\text { Sig. } \\
(2- \\
\text { tailed) }\end{array}$} \\
\hline & & \multirow[t]{2}{*}{ Mean } & \multirow[t]{2}{*}{$\begin{array}{c}\text { Std. } \\
\text { Deviation }\end{array}$} & \multirow{2}{*}{$\begin{array}{l}\text { Std. } \\
\text { Error } \\
\text { Mean }\end{array}$} & \multicolumn{2}{|c|}{$\begin{array}{l}95 \% \text { Confidence } \\
\text { Interval of the } \\
\text { Difference }\end{array}$} & & & \\
\hline & & & & & Lower & Upper & & & \\
\hline $\begin{array}{l}\text { Speaking } \\
\text { Skill }\end{array}$ & $\begin{array}{l}\text { Pretest - } \\
\text { Posttest }\end{array}$ & $4.24 \mathrm{E}+01$ & 4.6629 & 1.13092 & 44.75038 & 39.9555 & 37.5 & 16 & 0 \\
\hline
\end{tabular}

Berdasarkan nilai t-hitung pada output menunjukkan angka .37 .5 ini berarti terjadi peningkatan kemampuan speaking skill pada mahasiswa. Dengan $\mathrm{db}=\mathrm{n}-1$ diperoleh $\mathrm{db}-15$ pada taraf signifikan $5 \%$ maka didapatkan t-tabel $=2.20$. Dari hasil korelasi antara pretest dan post-test, menghasilkan angka korelasi 0.213 dengan nilai probabilitas di bawah bawah 0.05 yaitu sebesar 0.000. Hal ini menyatakan bahwa korelasi antara rata-rata pretest dengan rata-rata posttest konseling behavior therapy dengan teknik modelling adalah kuat dan signifikan.

Berdasarkan hasil data SPSS menunjukan konseling behavior therapy dengan teknik modelling dapat digunakan dalam meningkatkan kemampuan Speaking Skill mahasiswa. Teknik tersebut menjadi rekomendasi untuk mengatasi rendahnya keammpuan speaking skill pada mahasiswa.

\section{KESIMPULAN}

Salah satu kompetensi yang harus dimiliki seorang konselor adalah keahlian dalam berbicara. Mahasiswa yang memiliki kemampuan berbicara yang rendah, berdampak pada keaktifan pada saat perkuliahan dan pada aktifitas diluar perkuliahan. Sebagai mahasiswa bimbingan konseling, hal ini menjadi penghambat mahasiswa dalam mendapatkan hasil yang maksimal disetiap mata kuliah yang harus ditempuh. Berdasarkan hasil penelitian secara keseluruhan, konseling behavior therapy dengan teknik modelling dapat digunakan dalam meningkatkan 
kemampuan Speaking Skill mahasiswa. Hal ini dapat menjadi rekomendasi bagi konselor dalam mengatasi rendahnya keterampilan berbicara yang sering dialami oleh mahasiswa.

\section{DAFTAR PUSTAKA}

Arikunto, S. (2002). Prosedur Penelitain Suatu Pendekatan Praktek.Rineka Cipta: Jakarta.

Corey, G. (2015). Theory and Practice of Counseling and Psychotherapy. Book, Nelson Education.

Gladding, ST. (2012). Konseling Profesi yang Menyeluruh. Jakarta Barat : PT Indeks.

Hartono, et al. (2010). Psikologi Konseling Edisi Revisi. Surabaya: Kencana.

Nurbiana, D. (2005). Metode Pengembangan Bahasa. Jakarta: Universitas Terbuka.

Sanyata, S. (2012). Teori dan Aplikasi Pendekatan Behavioristik dalam Konseling. Jurnal Paradigma 14(7).

Shihahbuddin. (2009). Evaluasi Pengajaran Bahasa Indonesia. Bandung : UPI.

Sugiyono. (2008). Metode Penelitian Kuantitaf, Kualitatif dan R \& D. CV Alfabetha: Bandung.

Suhartono. (2005). Pengembangan Keterampilan Berbicara Anak Usia Dini. Jakarta : Depdiknas.

Wahyudi, MAS. (2017). Konsep Pendekatan Behavior Dalam Menangani Perilaku Indisipliner Pada Siswa Korban Perceraian. Jurnal Konseling GUSJIGANG. 41-52. ISSBN 2460-1187 